\title{
Genetic Diversity in the Coat Protein Genes of Prune dwarf virus Isolates from Sweet Cherry Growing in Turkey
}

\author{
Yusuf Öztürk ${ }^{1}$ and Bayram Çevik ${ }^{2 *}$ \\ ${ }^{I}$ Ministry of Food Agriculture and Livestock, Eğirdir Fruit Research Station, 32500, Isparta, Turkey \\ ${ }^{2}$ Department of Plant Protection, Faculty of Agriculture, Süleyman Demirel University, 32260 Isparta, Turkey \\ (Received on July 4, 2014; Revised on January 16, 2015; Accepted on February 3, 2015)
}

Sweet cherry is an important fruit crop with increasing economical value in Turkey and the world. A number of viruses cause diseases and economical losses in sweet cherry. Prune dwarf virus (PDV), is one of the most common viruses of stone fruits including sweet cherry in the world. In this study, PDV was detected from 316 of 521 sweet cherry samples collected from 142 orchards in $\mathbf{1 0}$ districts of Isparta province of Turkey by double antibody sandwich-enzyme linked immunosorbent assay (DAS-ELISA). The presence of PDV in ELISA positive samples was confirmed in 37 isolates by reverse transcription- polymerase chain reaction (RTPCR) method. A genomic region of 862 bp containing the coat protein (CP) gene of PDV was re-amplified from 21 selected isolates by RT-PCR. Amplified DNA fragments of these isolates were purified and sequenced for molecular characterization and determining genetic diversity of PDV. Sequence comparisons showed 8499\% to $81-100 \%$ sequence identity at nucleotide and amino acid level, respectively, of the $\mathrm{CP}$ genes of PDV isolates from Isparta and other parts of the world. Phylogenetic analyses of the CP genes of PDV isolates from different geographical origins and diverse hosts revealed that PDV isolates formed different phylogenetic groups. While isolates were not grouped solely based on their geographical origins or hosts, some association between phylogenetic groups and geographical origins or hosts were observed.

Keywords : coat protein gene, Prune dwarf virus (PDV), phylogenetic analysis, sequencing, sweet cherry

*Corresponding author.

Phone) 902462114737, FAX) 902462114885

E-mail)bayramcevik@sdu.edu.tr
Sweet cherry is an economically important stone fruit grown in temperate regions of Turkey and the world with increasing production. With an annual production of 480.748 tons, Turkey is the leading sweet cherry producers in the world providing about $20 \%$ of world production. Isparta province, especially Uluborlu district, is one of the most important sweet cherry production and exportation centers of Turkey (Anonymous, 2014). Although sweet cherry production has been increasing recently, pathogens, especially viruses, cause diseases reducing the yield and quality of fruits leading to significant economical losses. A number of viruses reported to cause diseases in sweet cherry (Myrta and Savino, 2008; Nemeth, 1986). Many studies in different regions showed that Prune dwarf virus (PDV) is the most widespread virus in sweet cherry production areas. It is generally found as mixed infections with Prunus necroctic ring spot virus (PNRSV) and Apple necroctic leaf spot virus (ACLSV) (Çevik et al., 2011; Mandic et al., 2007; Myrta and Savino, 2008). Previous studies reported that PDV infection rate was $67.2-80 \%$ in Mediterranean countries (Myrta et al., 2003; Myrta and Savino, 2008), $37.6 \%$ in Serbia (Mandic et al., 2007) and 5-55\% in Turkey (Çağlayan-Yıldızgördü and Hurigil, 1996; Çevik et al., 2011; Gümüş et al., 2007). Occurrence of PDV has previously been reported in different growing regions of Turkey including Aegean (Dunez 1986; Gümüş et al., 2007), Eastern Mediterranean (Çağlayan-Yıldızgördü and Hurugil 1996; Sertkaya et al., 2004), Western Mediterranean (Çevik et al., 2011), Eastern Anatolia (Sipahioglu et al., 1999), Central Anatolia (Elibüyük, 2003).

PDV is able to infect sweet cherry, sour cherry, apricot, plum and peach as well as other Prunus species by mechanical inoculation, grafting, pollens and seeds transmission (Nemeth, 1986). While PDV is commonly found in stone fruit production areas, severity of symptoms may vary based on host, virus strain and/or temperature (Diekmann and Putter, 1996). Trees infected with PDV generally have small and narrow or curled leaves, short internodes, 
and PDV also cause cholorotic ring spots especially on sweet cherry and sour cherry leaves (Sutic et al., 1999). Generally, PDV does not affect organs other than leaves, but mixed infection with PNRSV cause reduction in number of fruit buds and formation of leafless shoots (Kunze, 1988).

PDV belongs to Ilarvirusgenus in the Bromoviridae family and has a tripartite single-stranded positive-sense RNA genome. The segments of the genome are encapsidated by a single coat protein $(\mathrm{CP})$ into three isometric particles with a diameter of $19-26 \mathrm{~nm}$. The virus particles contain $14 \%$ nucleic acid and $86 \%$ protein and the $\mathrm{CP}$ is about $24 \mathrm{kDa}$ (Brunt et al., 1996; Halk and Fulton, 1978).

The CP gene has been used as target for serological and molecular detections as well as molecular characterization and genetic diversity studies of PDV isolates from different geographical origins and host plants (Bachmanet et al., 1994; Boulila, 2010; Ulubaș Serçe et al., 2009; Vaskova et al., 2000; Youssef et al., 2002). The CP gene sequences of $11 \mathrm{PDV}$ isolates from plum, sweet cherry and peach trees in Central Europe were determined. Comparison of the $\mathrm{CP}$ gene sequences of these isolates and two previously sequenced isolates showed that the $\mathrm{CP}$ gene are highly conserved with more than $88 \%$ identity in both nucleotide (nt) and amino acid (aa) sequences. The results also showed that the $\mathrm{C}$-terminal half of the $\mathrm{CP}$ was more conserved than the N-terminal half. No association with sequence variation within the CP gene and the geographic origins and/ or hosts of PDV isolates was observed (Vaskova et al., 2000). Comparison of the CP gene sequences of peach and plum isolates from Egypt and a sweet cherry isolate from the USA with previously sequenced peach isolate from the USA (Bachmanet al.,1994) showed 97\% and 98\% nt sequence identity, respectively (Youssef et al., 2002). The CP gene sequence of an almond isolate from Tunisia was determined and compared with previously sequenced PDV isolates in the GenBank databases. It showed 8696\% sequence similarity with the CP gene of PDV isolates from different host and geographical origins. Phylogenetic analysis of 32 PDV isolates revealed that they were divided into four distinct groups mostly correlated with geographical origin or recombination within the CP gene (Boulila, 2010). Sequence analyses of the CP gene of 10 PDV isolates, one from apricot and 9 from sweet cherry trees grown in different regions of Turkey, showed 87-99\% and 8499\% sequence identity at nt and aa level, respectively. Phylogenetic analysis of these isolates and other PDV isolates from different countries and various Prunus hosts revealed four distinct groups of isolates clustered largely based on their hosts. Group I and IV contained only sweet cherry and almond isolates, respectively. However, group II composed of apricot and sweet cherry isolates and the group III was most divers containing isolates from plum, peach, and sweet cherry (Ulubaş Serçe et al., 2009).

In this study, sweet cherry isolates of PDV from Isparta Province of Turkey, which is one of the most important sweet cherry production and export centers, was identified by double antibody sandwich (DAS)-ELISA and RT-PCR methods. The CP gene of isolates representing different districts were sequenced and compared with previously determined $\mathrm{CP}$ gene sequences of PDV isolates from different geographical origins and various Prunus hosts.

\section{Materials and Methods}

Field Surveys and plant materials. Surveys were conducted in spring of 2011 in 142 sweet cherry orchard in 10 different districts of Isparta Province located in southwestern Turkey. A total of 521 leaf samples were collected from sweet cherry trees showing PDV- or other virus-like symptoms.

DAS-ELISA. All collected samples were tested for the presence of PDV by DAS-ELISA method (Clark and Adams, 1977). DAS-ELISA test was performed with ELISA kits (Bioreba, Switzerland) containing the polyclonal antiserum recognizing all PDV isolates according to the manufacturer's recommendations. Results in the formation of the yellow color observed and ELISA absorbance values at a wavelength of $405 \mathrm{~nm}$ were measured in an ELISA reader.

Total RNA isolation. RNA was isolated from samples identified as PDV positive by ELISA results. Three different methods of total RNA or nucleic acid isolation including One Step RNA Solution (Bio-Basic, Canada) RNeasy Plant Mini Kit (Qiagen, Germany) and modified mini CTAB method (Li et al., 2008) were tested using a minimum number of samples. Considering the cost and efficiency, the modified CTAB total nucleic acid isolation method (Li et al., 2008) was used for all samples. Total nucleic extracts were dissolved in $100 \mu \mathrm{l}$ of $20 \mathrm{mM}$ Tris$\mathrm{HCl}, \mathrm{pH} 8.0$ and stored at $-80^{\circ} \mathrm{C}$ until used.

Reverse Transcription Polymerase Chain Reaction (RT-PCR). The CP gene of PDV was amplified by twostep RT-PCR method. First, cDNA was synthesized from $5 \mu 1$ total nucleic acid extracts using random primers and Revert-Aid cDNA kit (Fermentas, Canada) according to the manufacturer's instructions. Secondly the CP gene was amplified from synthesized cDNA using a previously 
Table 1. PDV isolates used in this study

\begin{tabular}{|c|c|c|c|c|}
\hline Accession number & Isolate & Host & Origin & Reference \\
\hline GU181400 & PDV-SW7 & Sweet cherry & Poland & Mroczkowska et al. 2009 unpub. \\
\hline EU170005 & $5 \mathrm{C} 3$ & Sweet cherry & Poland & Komorowska2007 unpub. \\
\hline AY554277 & RS-88/1 & Sweet cherry & Hungary & Krizbai and Nemeth 2004 unpub. \\
\hline AY554275 & $\mathrm{RS}-40 / \mathrm{B}$ & Sweet cherry & Hungary & Krizbai and Nemeth 2004 unpub. \\
\hline JF333587 & DJ1-2 & Sweet cherry & Çin & Zong et al. 2011 unpub. \\
\hline GU066792 & PDV-SW9-1 & Sweet cherry & USA & Sala-Rejczak et al. 2009 unpub. \\
\hline AF208740 & $21 / 1$ & Sweet cherry & Czech Republic & Vaskova et al. 2000 \\
\hline GU066793 & PDV-SW6-1 & Sweet cherry & Italy & Sala-Rejczak et al. 2009 unpub. \\
\hline AF208741 & vanC & Sweet cherry & Czech Republic & Vaskova et al. 2000 \\
\hline AF208737 & $2 / 16$ & Sweet cherry & Czech Republic & Vaskova et al. 2000 \\
\hline AY554278 & $\mathrm{RS}-45 / 1$ & Sweet cherry & Moldova & Krizbai and Nemeth 2004 unpub. \\
\hline EF524273 & PD10 & Sweet cherry & Afyon/Turkey & Ulubaş Serçe et al. 2009 \\
\hline EF524265 & PD2 & Sweet cherry & Adana/Turkey & Ulubaş Serçe et al. 2009 \\
\hline EF524267 & PD4 & Sweet cherry & K.Maraş/Turkey & Ulubaş Serçe et al. 2009 \\
\hline EF524269 & PD6 & Sweet cherry & Izmir/Turkey & Ulubaş Serçe et al. 2009 \\
\hline GU181399 & PDVSOF17P17 & Sour cherry & Italy & Mroczkowska et al. 2009 unpub. \\
\hline GU181404 & PDVSOF15P11 & Sour cherry & Italy & Mroczkowska et al. 2009 unpub. \\
\hline AY551441 & RS-10/4 & Sour cherry & Hungary & Krizbai and Nemeth 2004 unpub. \\
\hline AY554274 & RS-38/1 & Sour cherry & Hungary & Krizbai and Nemeth 2004 unpub. \\
\hline GU066786 & PDV-SO14 & Sour cherry & Poland & Mroczkowska et al. 2009 unpub. \\
\hline GU181405 & PDV-SO63 & Sour cherry & Poland & Mroczkowska et al. 2009 unpub. \\
\hline GU066796 & PDV-SO40E50 & Sour cherry & Israel & Sala-Rejczak et al. 2009 unpub. \\
\hline GU066794 & PDV-PL1-19 & Plum & Italy & Sala-Rejczak et al. 2009 unpub. \\
\hline GU181401 & PDV-PL13 & Plum & Poland & Mroczkowska et al. 2009 unpub. \\
\hline EU169997 & $2 \mathrm{~S} 1$ & Plum & Poland & Komorowska 2007 unpub. \\
\hline EU169996 & $1 \mathrm{~S} 2$ & Plum & Poland & Komorowska 2007 unpub. \\
\hline GU187047 & PDV-PE247 & Peach & Poland & Mroczkowska et al. 2009 unpub. \\
\hline EU169998 & 3B9 & Peach & Poland & Komorowska 2007 unpub. \\
\hline GU066798 & PDV-PE15-28 & Peach & Germany & Sala-Rejczak et al. 2009 unpub. \\
\hline FJ360750 & $\mathrm{MC1}$ & Peach & Brezilya & Fajardo et al. 2008 unpub. \\
\hline EU170006 & $4 \mathrm{M} 2$ & Apricot & Poland & Komorowska 2007 unpub. \\
\hline EU170008 & $9 \mathrm{M} 1$ & Apricot & Poland & Komorowska 2007 unpub. \\
\hline EF524264 & PD1 & Apricot & Hatay/Turkey & Ulubaş Serçe et al. 2009 \\
\hline GU066795 & PDV-AL2 & Almond & Italy & Sala-Rejczak et al. 2009 unpub. \\
\hline AY646843 & $4 \mathrm{~B}$ & Almond & Portugal & Fonseca et al. 2005 \\
\hline KF718677 & PDV-CPG-U30 & Sweet cherry & Isparta/Turkey & This study \\
\hline KF718678 & PDV-CPG-U79 & Sweet cherry & Isparta/Turkey & This study \\
\hline KF718673 & PDV-CPG-S2 & Sweet cherry & Isparta/Turkey & This study \\
\hline KF718674 & PDV-CPG-S26 & Sweet cherry & Isparta/Turkey & This study \\
\hline KF718670 & PDV-CPG-S108 & Sweet cherry & Isparta/Turkey & This study \\
\hline KF718671 & PDV-CPG-S119 & Sweet cherry & Isparta/Turkey & This study \\
\hline KF718672 & PDV-CPG-S150 & Sweet cherry & Isparta/Turkey & This study \\
\hline KF718667 & PDV-CPG-M1 & Sweet cherry & Isparta/Turkey & This study \\
\hline KF718669 & PDV-CPG-M4 & Sweet cherry & Isparta/Turkey & This study \\
\hline KF718668 & PDV-CPG-M27 & Sweet cherry & Isparta/Turkey & This study \\
\hline KF718665 & PDV-CPG-K7 & Sweet cherry & Isparta/Turkey & This study \\
\hline KF718666 & PDV-CPG-K8 & Sweet cherry & Isparta/Turkey & This study \\
\hline KF718664 & PDV-CPG-K10 & Sweet cherry & Isparta/Turkey & This study \\
\hline KF718660 & PDV-CPG-A1 & Sweet cherry & Isparta/Turkey & This study \\
\hline KF718661 & PDV-CPG-A17 & Sweet cherry & Isparta/Turkey & This study \\
\hline KF718662 & PDV-CPG-Go1 & Sweet cherry & Isparta/Turkey & This study \\
\hline KF718663 & PDV-CPG-Go9 & Sweet cherry & Isparta/Turkey & This study \\
\hline KF718675 & PDV-CPG-Sa12 & Sweet cherry & Isparta/Turkey & This study \\
\hline KF718676 & PDV-CPG-Sa15 & Sweet cherry & Isparta/Turkey & This study \\
\hline KF718680 & PDV-CPG-G1 & Sweet cherry & Isparta/Turkey & This study \\
\hline KF718679 & PDV-CPG-Y3 & Sweet cherry & Isparta/Turkey & This study \\
\hline
\end{tabular}


reported forward (5' AAA GAA GAG AAG TCC GAC AAG 3') reverse (5' AAG CAG CAT TTC CAA CTA CGA 3') primers specific to the up-and downstream region of PDV CP gene (Vaskova et al., 2000) and ExTaq DNA polymerase (Takara, Japan). PCR amplification was conducted in $50 \mu \mathrm{l}$ reaction mixture with $1 \mathrm{X}$ PCR buffer $\left(50 \mathrm{mM} \mathrm{KCl}, 10 \mathrm{mM}\right.$ Tris $\mathrm{HCl} 25^{\circ} \mathrm{C} \mathrm{pH}$ 9.0, 0.1\% Triton $\mathrm{X}-100), 0.5 \mathrm{mM}$ dNTP, $20 \mathrm{pmol}$ of each gene specific primer, 2.5 unit ExTaq DNA polymerase and $5 \mu \mathrm{l}$ cDNA. The amplification was performed in $\mathrm{C} 1000$ Thermal Cycler (Bio-Rad, USA) programmed for $94 \mathrm{C} 2 \mathrm{~min}$, followed by 40 cycles of $94^{\circ} \mathrm{C} 30 \mathrm{~s}, 57^{\circ} \mathrm{C}$ in $1 \mathrm{~min}$ and $72^{\circ} \mathrm{C} 1 \mathrm{~min}$. The PCR products were separated in $1 \%$ agarose gel with 100 bp plus DNA size marker (Fermantas, Canada) by electrophoresis, stained with ethidium bromide and visualized by EL Logic 200 imaging system (Kodak, USA).

Sequencing and sequence analyses. The CP genes amplified by RT-PCR were purified by EZ spin column PCR purification kit (Biobasic, Canada) according to the manufacturer's instructions. The purified DNAs were directly sequenced bi-directionally using primers specific to up and downstream of PDV CP gene. The sequences obtained for each isolate were cleaned, compared, and analyzed by Vector NTI software to obtain the nucleotide sequence containing the $\mathrm{CP}$ gene. The ORF encoding the $\mathrm{CP}$ gene and the deduced amino acid sequences were determined in Vector NTI. Then, nucleotide and amino acid sequences of PDV isolates from various stone fruit hosts and different geographical regions of the world were retrieved from GenBank databases (Table 1). Multiple sequence comparison of nucleotide and amino acid sequences of the $\mathrm{CP}$ genes of PDV isolates from different districts of Isparta province and from various sweet cherry and other stone fruit production regions across the world were conducted by the AlignX module of Vector NTI software and their percent sequence identity was determined at nucleotide and amino acid levels. The phylogenetic analyses were performed Clustal X2 software using multiple sequence alignments generated in AlignX. Phylogenetic trees were constructed by the neighbor-joining method using Kiamura two-parameter algorithm. The statistical significance of the clusters and branches of the phylogenetic trees was tested by 'bootstrap' analysis with 1000 replications. Finally, the phylogenetic trees were visualized by TreeView software. To determine genetic relations among PDV isolates from Turkey and other part of the world two different phylogenetic analyses was performed. In the first analysis, genetic relationship and phylogenetic grouping were determined among PDV isolates of from different geographical regions and different hosts. In the second phylogenetic analysis, genetic relationship and grouping among sweet cherry only PDV isolates from different geographical origins were determined independently of host variations.

\section{Results}

Field surveys. Leaf samples were collected from 521 trees from 142 commercial orchards in 10 different districts of Isparta Province. The samples were distributed to the districts proportionally considering to amount of sweet cherry production area and amount production. Sweet cherry trees from which the samples were collected were generally dwarf compared to the surrounding trees and showed general chlorosis and had ruptured, narrowed and thinned leaves and thin and leafy lateral shoots. Symptoms of shot holes, chlorotic ring spots and mosaic were also observed in leaves of these trees. Some of the sampled trees showed only one of these symptoms while others displayed several symptoms together. '0900 Ziraat' was the major sweet cherry variety grown in surveyed orchards, however, samples were also collected from 'Starks Gold' (white cherry) and 'Sweet Heart' varieties. Fig. 1 shows symptoms observed in some of the collected samples suspected to be infected with PDV. These samples and some symptomless leaves were later tested PDV positive in the laboratory.

Detection of PDV by ELISA test. Sample brought to the laboratory were kept at $4^{\circ} \mathrm{C}$ and they were first tested by ELISA within 3 days. DAS-ELISA revealed that 316 of 521 tested samples were infected with PDV and the pres-

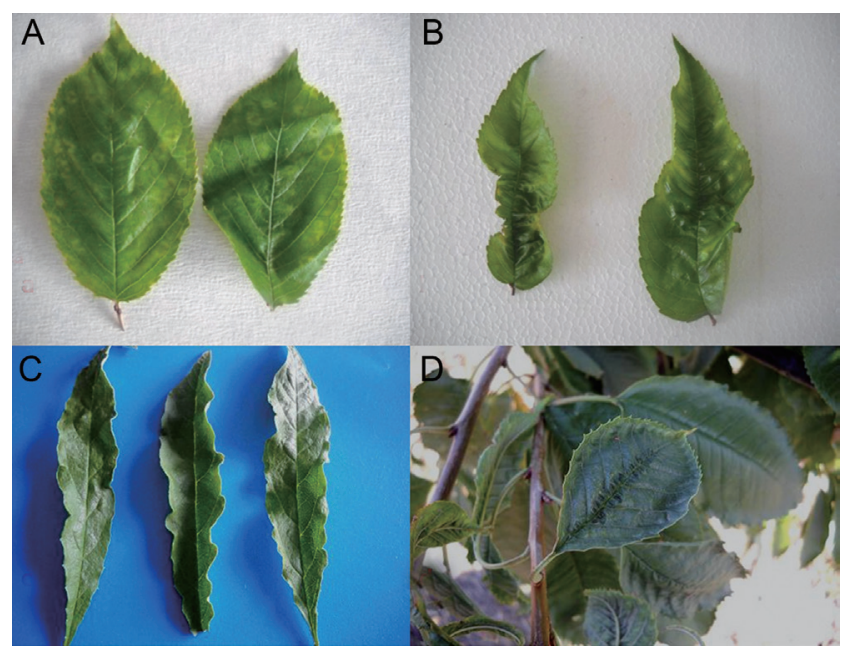

Fig. 1. Symptoms observed in sweet cherry trees with suspected PDV infection. (A) Chlorotic ring spots on leaves. (B) Deformations and wrinkles along the veins on leaves. (C) Leaf elongation. (D) Density of teeth near the leaf edge. 
Table 2. Summary of DAS-ELISA results for detection of PDV in different districts of Isparta Province

\begin{tabular}{lccccc}
\hline Location & $\begin{array}{c}\text { Number of } \\
\text { orchards }\end{array}$ & $\begin{array}{c}\text { Total No. of samples } \\
\text { tested }\end{array}$ & $\begin{array}{c}\text { Number of PDV } \\
\text { infected samples }\end{array}$ & $\begin{array}{c}\text { Number of healthy } \\
\text { samples }\end{array}$ & $\begin{array}{c}\text { Infection rate } \\
(\%)\end{array}$ \\
\hline Uluborlu & 44 & 160 & 115 & 45 & 71.88 \\
Senirkent & 39 & 166 & 103 & 63 & 62.05 \\
Merkez & 16 & 42 & 26 & 16 & 61.90 \\
Atabey & 20 & 48 & 27 & 21 & 56.25 \\
Gönen & 6 & 15 & 8 & 7 & 53.33 \\
Yalvaç & 3 & 10 & 2 & 8 & 20.00 \\
Gelendost & 2 & 10 & 6 & 4 & 60.00 \\
Şarkıkaraağaç & 4 & 27 & 10 & 9 & 37.04 \\
Keçiborlu & 4 & 23 & 8 & 15 & 55.00 \\
Eğirdir & 4 & 521 & 316 & 205 & 34.78 \\
\hline Total & 142 & & & & 60.27 \\
\hline
\end{tabular}

ence of PDV was determined in all sweet cherry producing districts surveyed. The PDV infection rate of sweet cherry trees ranged from $20 \%$ to $71.88 \%$ in different production regions of Isparta. With $71.88 \%$ infection rate Uluborlu had the highest number of PDV infected trees followed by Senirkent (62.05\%) and Isparta Merkez (61.9\%). On the other hand, the lowest level of PDV infection was detected in Yalvaç with an infection rate of 20\% (Table 2).

Amplification sequencing and sequence analyses. A total of 37 samples determined PDV positive by DAS-ELISA were selected and a DNA fragment containing the CP gene was amplified by RT-PCR method. An 862 bp fragment was amplified from all 37 samples tested confirming the DAS-ELISA results. The results showed that all 37 isolates tested by RT-PCR were infected with PDV. Among these samples 21 of them were selected based on the amount of the production to represent all sweet cherry growing areas of the region under study. The $862 \mathrm{bp}$ fragment containing the CP gene was re-amplified from these 21 samples in a larger amount. The 862 bp fragment obtained from all 21 isolates were purified and used for sequencing the CP gene of PDV. The amplification of the CP gene containing fragment of some PDV isolates are shown in Fig. $2 b$.

The RT-PCR products were sequenced by PDV1 and PDV2 primers bi-directionally and about 750-800 bp sequence was obtained for each direction. These sequences were compared and combined to identify sequence of 657 bp containing an ORF encoding the CP gene of the 21 PDV isolates (Fig. 2a). In addition, deduced amino acid sequences (219 aa) were determined for all PDV isolates.

Nucleotide and deduced amino acid sequences of the $\mathrm{CP}$ genes of 35 isolates across the world including 5 previously sequenced PDV isolates from Turkey were retrieved from the GenBank databases. Comparisons of the CP gene sequences of PDV isolates from Isparta with those from other parts of the world revealed that while isolates were 84-99\% identical in their nt sequence, their aa sequence identity was ranged from 81 to $100 \%$. With a $99 \%$ identity in nucleotide sequence Yalva 3 and Afyon sweet cherry
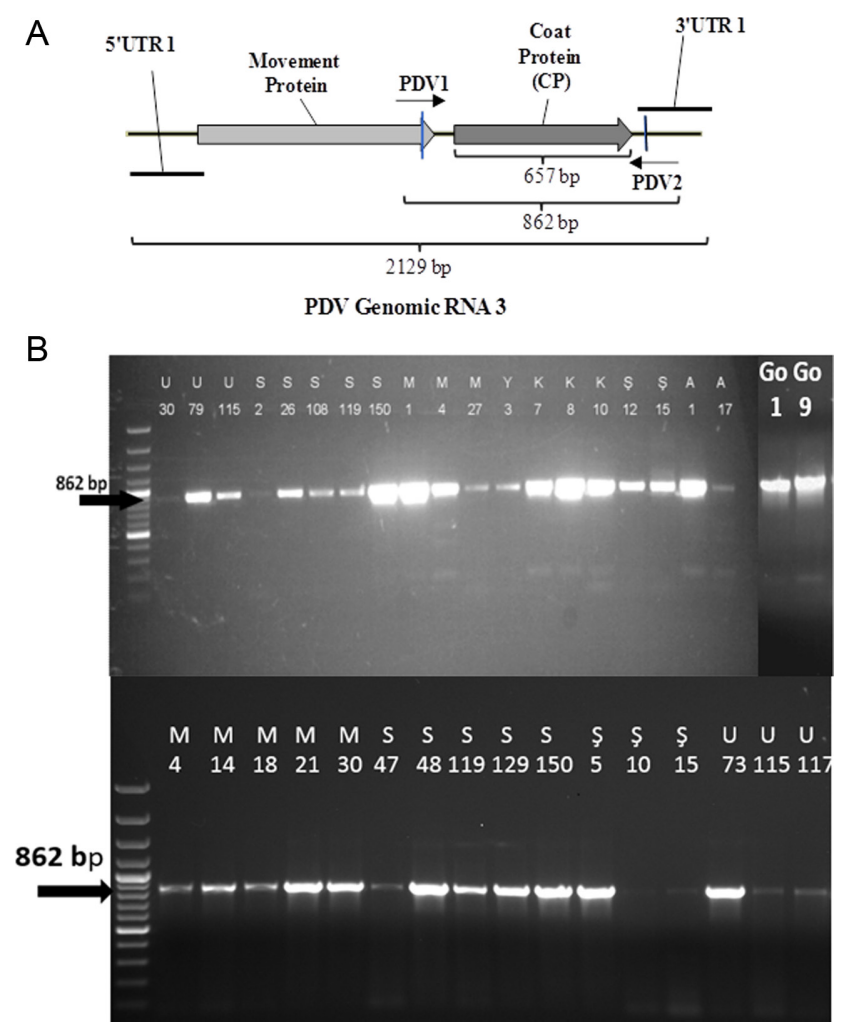

Fig. 2. (A) The map of RNA3 of PDV genome and region amplified by RT-PCR analysis. (B) The amplification of $862 \mathrm{bp}$ fragment containing the $\mathrm{CP}$ gene from selected PDV isolates collected from different districts of Isparta Province. Letters and numbers at the top indicate the names of isolates. 
isolates were the most similar followed by Merkez 1 with two sweet cherry isolates, PDV-SW9-1 from USA and 21/1 from Czech Republic and Şarkikaraagaç 12 with RS-38/1, a sour cherry isolate from Hungary with $98 \%$ identity. It was found that with a $84 \%$ sequence identity Atabey 17 isolate was least similar to RS-40B/1, a sweet cherry isolate from Hungary. Comparisons of the deduced aa sequences showed that with a $100 \%$ sequence identity Merkez 1 and a sweet cherry isolate from İzmir, Turkey were the most similar isolates. In addition, 99\% identity was found between Şarkikaraagaç 12, and PDVSOF15P11, a sour cherry isolate from Italy, PDV-SO63, a sour cherry isolate from Poland, PDV-AL2, a almond isolate from Italy, and between Uluborlu 79 and PDVSOF15P11, a sour cherry isolate from Italy, and PDV-AL2, a almond isolate from Italy, as well as between Merkez 1 and PDVAL2, a almond isolate from Italy and 21/1, a sweet cherry isolate from Czech Republic. On the other hand, with $81 \%$ sequence identity Atabey 17 isolate was the least similar to RS-40B/1, a sweet cherry isolate from Hungary, at the aa sequence.

Phylogenetic analyses. Phylogenetic analysis of nucleotide and amino acid sequences of the $\mathrm{CP}$ genes of 35 previously sequenced PDV isolates from different geographical regions and various Prunus hosts and the CP gene of 21 isolates sequenced in this study revealed PDV isolates related to each other. However, the isolates were divided into 3 major phylogenetic groups. The first major group was divided into 3 subgroups, namely 1a, 1b and 1c. Subgroup 1a contained five sweet cherry isolates from Isparta and 12 PDV isolates from different Prunus hosts including sweet cheery, plum, apricot sour cherry and peach from different countries. Second subgroup,1b, was more uniform and consisted only sweet cherry isolates only from Turkey, except one sour cherry isolates from Hungry. The sub group 1c consisted of three isolates, two sour cherry isolates from Italy and Poland and one sweet cherry isolate from Turkey. Isolates in the major groups 2 and 3 were more closely clustered and were not clearly divided into subgroups. The major group 2 contained PDV isolates from different geographical origins, mostly from European countries, and different host such as sweet cherry, sour cherry, peach, plum and almond. Only one of the PDV isolates sequenced in this study located in this group. The cluster also contained one previously sequenced PDV sweet cherry isolates from Turkey (Fig. 3). The major group 3 was consisted of only sweet cherry isolates from Turkey, Hungary and Poland (Fig. 3). The results showed that although no clear association between phylogenetic groups or subgroups and geographical origin of PDV isolates were observed, some phylogenetic groups (such as 3) and subgroup (such as 1b) consisted of PDV isolates only from sweet cherry host indicating some association with these phylogenetic grouping and the host.

Another phylogenetic analysis was performed only with PDV isolates from sweet cherry To determine genetic relationship and grouping among PDV isolates independent of host variations. When phylogenic analysis was conducted only with PDV isolates from sweet cherry trees, similar phylogenetic grouping was observed. Three major groups were clearly distinguished in phylogenetic tree constructed using nucleotide sequences of only sweet cherry isolates. The largest major group 1 was divided into 2 subgroups (1a and 1b). While major group 2 was also divided in to two smaller sub-groups, group 3 was not divided into subgroups. The majority of PDV isolates from Isparta were

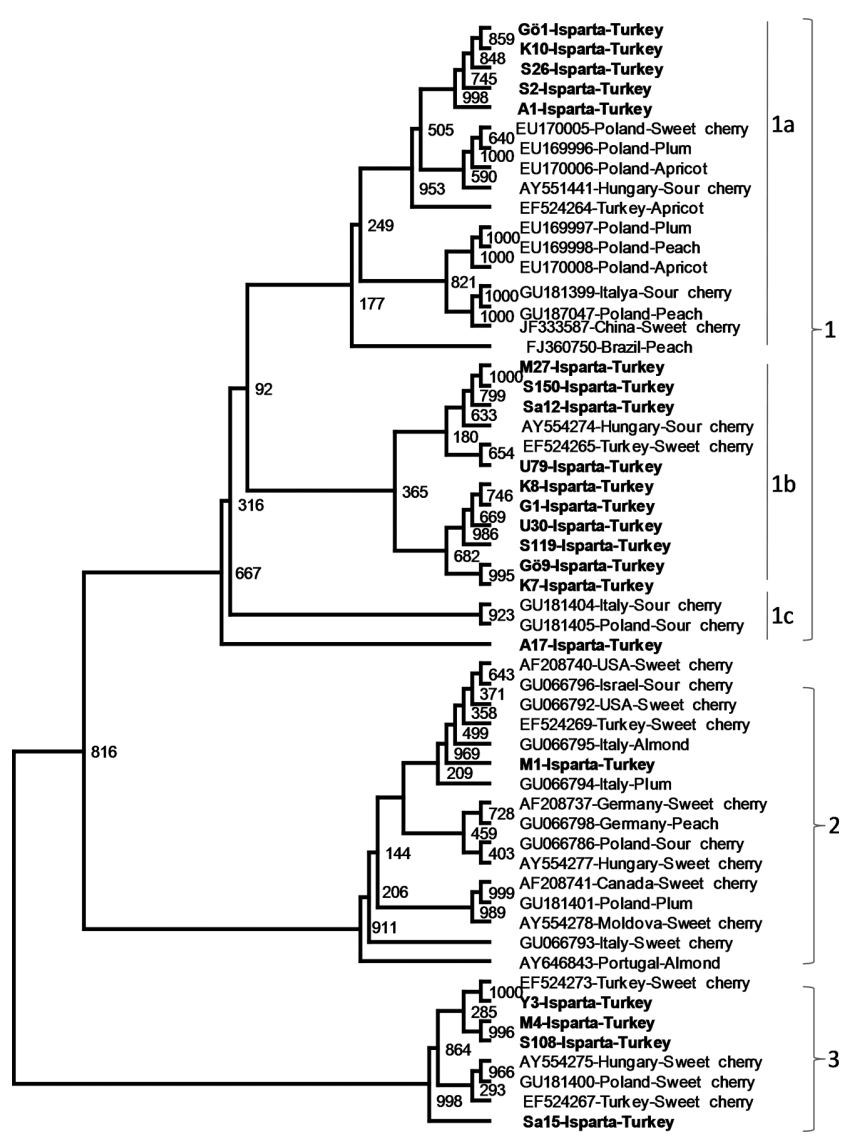

Fig. 3. The phylogenetic tree showing genetic relationship among PDV cherry isolates from Isparta and PDV isolates from different Prunus host collected from different stone fruits production regions of the world. The phylogenetic tree was constructed with the $\mathrm{CP}$ gene sequences of PDV isolates using neighbor joining algorithm ClustalX2 and visualized by TreeView program. The $\mathrm{CP}$ gene of PRNSV was used as outgroup. 
placed in major group 1 which was divided into two subgroups. While the subgroup 1a consisted only of Turkish isolates, subgroup contained one isolate from Poland and one isolated from China. The major group 2 consisted of different isolates from diverse geographical origin. Two Turkish PDV isolates, one from Isparta and one from İzmir, were clustered with isolates from five different countries. On the other hand, major group 3 was mostly consisted of Turkish isolates and the cluster contained only two eastern European isolates (Fig. 4). Phylogenetic analyses of nt sequence of the CP gene of PDV isolates only from sweet cherry trees showed no clear association between phylogentic groups and geographic origins of the isolates analyzed. Although the isolates were not grouped according to geographic regions they were collected, some groups consisted mostly from Turkish isolates. The result

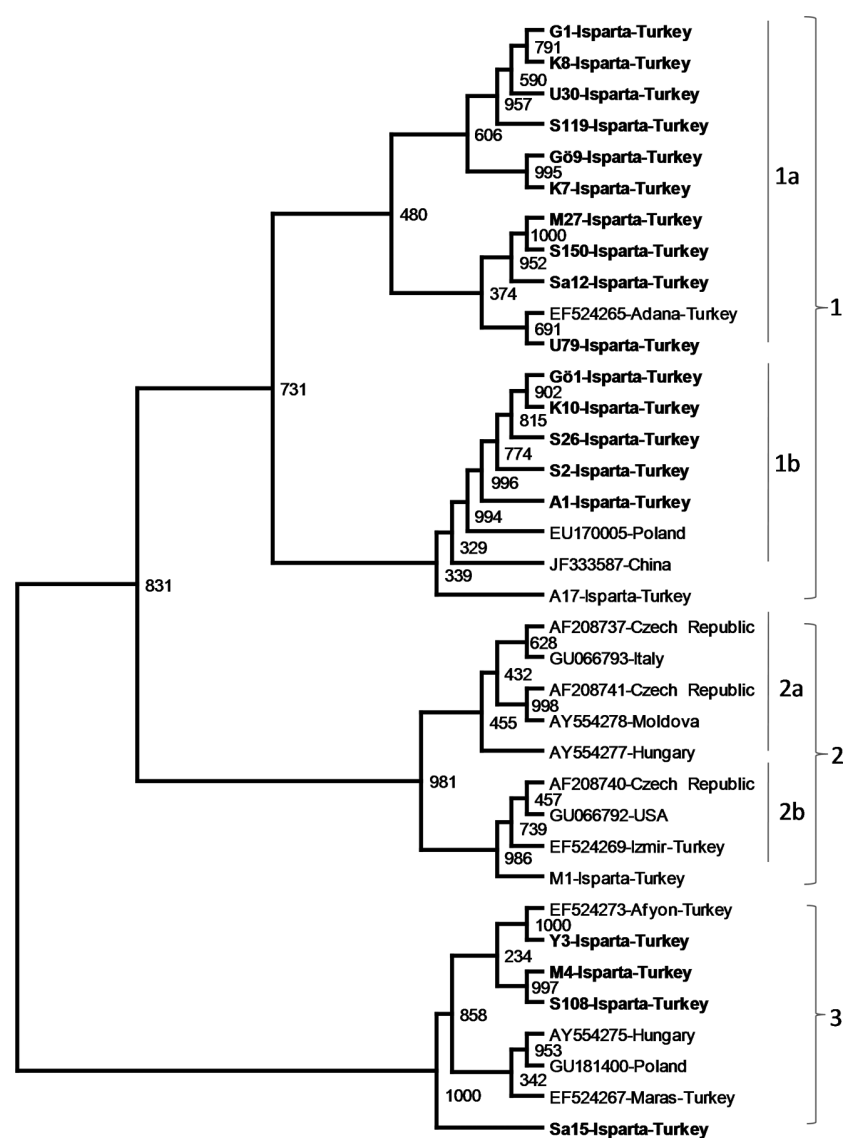

Fig. 4. The phylogenetic tree showing genetic relationship among PDV cherry isolates from Isparta and different stone fruit production regions the world. The phylogenetic tree was constructed with the CP gene sequences of PDV isolates using Neighbor joining algorithm ClustalX2 and visualized by TreeView program. The CP gene of PRNSV was used as outgroup. suggested that lineages of PDV isolates were not developed based on the geographical regions of the isolates but phylogenetic clustering is not completely independent from the geographical origins.

\section{Discussion}

Detection of PDV in 316 of 521 sweet cherry samples collected from trees distributed 142 commercial orchards showed that majority of sweet cherry trees (60.27\%) were infected with PDV. Findings of serological tests conducted in this study were similar to previous findings PDV was reported as the most frequently encountered virus in surveys of all stone fruits in other Mediterranean countries (Myrta et al., 2003) and other parts of Turkey including İzmir (Gümüş et al., 2007) and in Isparta (Çevik et al., 2011). Many studies conducted in Turkey and across the world showed that ELISA still is the most frequently used test for identification of stone fruit viruses (Akbaş et al., 2011; Aneliya, 2005; Çaglayan Yıldızgördü and Çalı, 1994; Çevik et al., 2011; Gümüş at al., 2007; Ismaeil et al., 2003; Mandic et al., 2007; Myrta et al., 2003; Myrta and Savino, 2008; Sertkaya et al., 2004; Ulubaş and Ertunç, 2004). This study also showed that despite certain drawbacks associated with DAS-ELISA method, it can efficiently be used for identification of PDV in samples collected in early spring period.

Leaf samples collected early spring were kept two different ways for RNA isolation. While a portion of the same sample was stored at $-80^{\circ} \mathrm{C}$ another part dried by a previously reported method and stored at $4^{\circ} \mathrm{C}$ (Sipahioğlu et al., 2006). The results reported that leaf samples can effectively be used after they are dried. The leaf samples were frozen at $-80^{\circ} \mathrm{C}$ or dried and stored at $4^{\circ} \mathrm{C}$, were successfully used for RNA isolation 2-3 months after they were treated. No difference was observed in quantity and quality of RNA isolated from samples stored at these two conditions. However, storage of leaf samples at $4^{\circ} \mathrm{C}$ after drying was found to be more suitable since application is easier and do not require any equipment.

We have use different methods including One StepRNA Solution, modified CTAB buffer (Li et al., 2008) and RNeasy Plant Mini Kit for nucleic acid isolation. No RNA was isolated in any of the samples with One StepRNA Solution whereas RNA was obtained through modified CTAB method and RNeasy Plant Mini Kit. A pinkred pellet formation was observed in RNA isolated from most samples by One Step-RNA Solution suggesting that this method fails to remove phenolic compounds present in sweet cherry leaves. Li et al. (2008) reported that both CTAB and RNeasy Kit methods can effectively be used 
for isolation of RNA with acceptable quality and quantity from sweet cherry and other plants with high phenolics and polysaccharide content. Although generally similar methods have been used for isolation of RNA from sweet cherry in previous studies, silica gel method has been the most frequently used method (Boom et al., 1990; Rott and Jelkman 2001). The results from the present study showed that an easily applicable and cost-effective method like the modified mini CTAB method can also be effectively used in detection and identification of PDV other virus of sweet cherry and possibly other stone fruits.

Comparison of the CP genes of PDV Isparta isolates shared $84-99 \%$ and $81-100 \%$ in nucleotide and amino acid sequences respectively with those of PDV isolates from across the world indicating CP gene were highly conserved among PDV isolates from different hosts and different geographical regions. Vaskova et al. (2000) found that the CP genes PDV isolates were conserved $88 \%$ based on comparison of their nt sequences. In another study, it was observed that Egyptian PDV isolates and American sweet cherry isolates of PDV showed 97\% and 98\% sequence identity with an American PDV isolate from peach, respectively (Youssef et al., 2002). The findings in this study showed that genetic variations among some of Turkish PDV isolates from sweet cherry were more than previously reported variations among other PDV isolates. PDV Isparta isolates shared the highest nt similarity with previously sequenced Turkish sweet cherry isolates as well as, a sweet cherry isolate from USA and sour cherry isolates from Hungary. On the other hand the lowest sequence similarity was observed with Hungarian sweet cherry isolate. Based on aa sequences, PDV isolates from Isparta were most similar with sweet cherry isolates from Turkey, Italy, Poland and USA and an almond isolates from Italy. On the other hand, they showed the lowest level of similarity with a Hungarian sweet cherry isolates. The results suggested that with a few exceptions the CP genes of PDV isolates from Eastern Europe and Mediterranean region were highly conserved. This may be due to frequent transfer and exchange of plant materials among these countries and Turkey.

Phylogenetic analysis of the CP genes showed that sweet cherry isolates of PDV can be divided into 3 major groups related with each other. Although most PDV isolates from Isparta were clustered together in different subgroups of the group 1 and 3, only one isolate, Merkez 1, was associated with group 2 containing isolates from various countries and different hosts. The phylogenic grouping of PDV isolates was similar to those obtained by Ulubaş-Serçe et al. (2009) suggesting that PDV isolates are genetically conserved and phylogenetically divided into three related groups. Phyloge- netic analysis of PDV isolates from different Prunus hosts and various countries revealed that phylogenetic grouping was not formed solely based on geographical origin and or the hosts of isolates. However some phylogenetic groups (such as 3) and subgroups (such as 1b) were associated with host of the PDV isolates mainly sweet cherry isolates clustering together. This association is need to be tested statistically using the $\mathrm{CP}$ genes of more PDV isolates from more diverse hosts.

Phylogenetic analysis of only sweet cherry isolates of PDV were conducted to determine the association between the geographical origins and the phylogenetic grouping of PDV isolates in the absence the host variation. Sweet cherry isolates of PDV were also divided into 3 major groups related with each other. Results from this study was similar to those found by Vaskova et al. (2000) evidenced that variations in $\mathrm{nt}$ and aa sequences were not directly related to hosts or geographic regions from which isolates are collected. While groups 1 and 3 were mostly consisted of Isparta isolates with the exception of two isolates from other countries, the group 2 was more diverse in terms of geographical origins of containing isolates from many different countries. Sequence comparison and phylogenetic analysis of PDV isolates in this study indicated that with a few exceptions isolates from Isparta can be divided to two groups consisting of genetically similar isolates showing high degree of identity in their CP gene sequences. Low genetic diversity among PDV isolates from Isparta indicated that virus isolates are generally spread by pollen or propagative materials and there is not an intensive selection pressure on PDV on sweet cherry trees in the region.

\section{Acknowledgments}

This study was supported by Suleyman Demirel University Research Found project 2235-YL-10 and Ministry of Food, Agriculture and Livestock of Turkey, General Directorate of Agricultural Research and Policies research project TAGEM-BS-1004-02/02-13.

\section{References}

Anonymous, 2014. http://faostat.fao.org

Aneliya, B. 2005. Preliminary Results of The Study on The Spread Of Apple Chlorotic Leaf Spot Virus (ACLSV) In Different Fruit Tree Species In Kyustendil Region of Bulgaria. Not. Bot. Horti. Agrobo. 33:82-86.

Akbaş, B., Değirmenci, K., Çiftçi, O., Kaya, A., Yurtmen, M., Uzunoğulları, N., Çelik, N. and Türkölmez, Ş. 2011. Update on Plumpox virus distribution in Turkey. Phytopathol. Mediterr. 50:75-83. 
Brunt, H. A., Crabtree, K., Dallawitz, M. J., Gibbs, A. J. and Watson, L. 1996. Viruses of plants. CAB International, Cambridge, UK.

Boulila, M. 2010. Molecular characterization of an almond isolate of Prune dwarf virus in Tunisia: putative recombination breakpoints in the partial sequences of the coat proteinencoding gene in isolates from different geographic origin. Phytopathol. Mediterr. 48:411-421.

Boom, R., Sol, C. J. A., Salimans, M. M. M., Jansen, C. L., Wertheim Van Dillen, P. M. E. and Van Der Noordaa, J. 1990. Rapid and Simple Method for Purification of Nucleic Acids. $J$. Clin. Microbiol. 28:495-503.

Clark, M. F. and Adams, A. N. 1977. Characteristics of the micro plate method of Enzyme Linked Immunosorbent Assay for the detection of plant viruses. J. Gen. Virol. 34:475-48.

Çağlayan Yıldızgördü, K. and Hurigil, H. 1996. Virus Diseases of Peach Trees in Hatay Province. J. Turk. Phytopathol. 25:6569.

Çevik, B., Yardimci, N. and Çulal Kılıç, H. 2011. Detection of Viruses Infecting Stone Fruits in Western Mediterranean Region of Turkey. Plant Pathol. J. 27:44-52.

Diekmann, M. and Putter, C. A. J. 1996. FAO/IPGRI technical guidelines for the safe movement of germplasm. In: Stone fruits, eds. by M. Diekmann, pp. 109-111. C. A. J. FAO Publication Division, Rome, Italy.

Elibuyuk, İ. Ö. 2003. Natural Spread of Plum Pox Virus in Ankara, Turkey. J. Phytopathol. 151:617-619.

Fonseca, F., Neto, J. D., Martins, V. and Nolasco, G. 2005. Genomic variability of Prune dwarf virus as affected by agricultural practice. Arch. Virol. 150:1607-1619.

Gümüş, M., Paylan, I. C., Matic, S., Myrta, A., Sipahioglu, H. M. and Erkan, S. 2007. Occurrence and Distribution of Stone Fruit Viruses and Viroids In Commercial Plantıngs Of Prunus Species In Western Anatolia, Turkey. J. Plant Pathol. 89:265268.

Halk, E. L. and Fulton, R. W. 1978. Stabilization and particle morphology of prune dwarf virus. Virology. 91:434-443.

Ismaeil, F., Myrta, A., Abou Ghanem-Sabanadzovic, N., Al Chaabi, S., Chik Darwich, A. and Savino, V. 2003. Viruses of Stone Fruit Trees in Syria. In: Virus and virus-like diseases of stone fruits, with particular reference to the Mediterranean region, eds. by A. Myrta, B. Di Terlizzi, V. Savino, pp. 37-38. Options Méditerranéennes, Bari, Italy.

Kunze, L. 1988. Prune dwarf virus (PDV). In: European handbook of plant diseases, eds. by I.M. Smith, J. Dunez, R.A. Lelliott, D.H. Phillips and S.A. Archer, pp. 15-17. Blackwell Scientific Publications, Oxford, UK.

Li, R., Mock, R., Huang, Q., Abad, J., Hartung, J. and Kinard, G. 2008. A reliable and inexpensive method of nucleic acid extraction for the PCR-based detection of diverse plant pathogens. J. Virol. Methods. 154:48-55.

Mandic, B., Matic, S., Rwahnih, M. A. L., Jelkman, W. and
Myrta, A. 2007. Viruses of Sweet and Sour Cherry in Serbia. $J$. Plant Pathol. 89:103-108.

Myrta, A., Di Terlizzi, B., Savino, V. and Martelli, G. P. 2003. Virus diseases affecting the Mediterranean stone fruit industry: a decade of surveys. In: Virus and virus-like diseases of stone fruits, with particular reference to the Mediterranean region, eds. by A. Myrta, B. Di Terlizzi, V. Savino, pp. 15-23. Options Méditerranéennes, Bari, Italy.

Myrta, A. and Savino, V. 2008. Virus and Virus-Like Diseases Of Cherry In The Mediterranean Region. Acta Hortic. 795:891896.

Nemeth, M. 1986. Virus, Mycoplasma and Rickettsia Diseases of Fruit Trees. Martinus Nijhoff Publishers, Dordrecht, The Netherlands, $840 \mathrm{pp}$.

Rampitsch, C. and Eastwell, K. C. 1997. The complete sequence of prune dwarf ilarvirus RNA 1. Arch. Virol. 142:1911-1918.

Rott, M. E. and Jelkman, W. 2001. Characterization and Detection of Several Filamentous Viruses of Cherry: Adaption of an Alternative Cloning Method (DOP-PCR), and Modification of an RNA Extraction Protocol. Eur. J. Plant Pathol. 107: 411-420.

Sertkaya, G., Caglayan, K. and Ulubas, C. 2004. Detection of Some Viruses of Stone Fruits In Mother Plant Blocks In Eastern Mediterranean Region Of Turkey. Acta Hortic. 657:127132.

Sipahioglu, H. M., Myrta, A., Abou-Ghanem, N., Di Terlizzi, B. and Savino, V. 1999. Sanitary status of stone-fruit trees in East Anatolia (Turkey) with particular reference to apricot. EPPO Bull. 29:439-442.

Sipahioğlu, H. M., Usta, M. and Ocak, M. 2006. Use of dried high-phenolic laden host leaves for virus and viroid preservation and detection by PCR methods. J. Virol. Methods. 137: $120-124$.

Sutic, D. D., Ford, R. E. and Tosic, M. T. 1999. Virus diseases of fruit trees, In: Handbook of plant virus diseases, CRC Press, Boca Raton, FL, USA.

Ulubas, C. and Ertunc, F. 2004. RT-PCR Detection and Molecular Characterization of Prunus necrotic ringspot virus Isolates Occurring in Turkey. J. Phytopathol. 152:498-502.

Ulubas Serce, C., Ertunc, F. and Öztürk, A. 2009. Identification and Genomic Variability of Prune dwarf virus Variants Infecting Stone Fruit Trees in Turkey. J. Phytopathol. 157:298305.

Vaskova, D., Petrzik, K. and Spak, J. 2000. Molecular variability of the capsid protein of the prune dwarf virus. Eur. J. Plant Pathol. 106:573-580.

Youssef, S. A., Shalaby, A. A., Mazyad, H. M. and Hadidi, A. 2002. Detection and identification of prune dwarf virus and plum pox virus by standard and multiplex RT-PCR probe capture hybridization (RT-PCR-ELISA). J. Plant Pathol. 84: 113-119. 